notation of the type (93), 126, (134), (152) and an explanatory note at the beginning of the Index would have obviated this confusion.

However, such minor criticisms become insignificant when viewed in the perspective of the work as a whole. Dr. McMillin's study is a major achievement in an area of
Byelorussian studies which has been sadly neglected, and can be highly recommended 'to anyone with an interest in Byelorussian lexicology or indeed Byelorussian linguistics in general. Furthermore, at the remarkably low price of $\mathfrak{2} 2$ it represents extremely good value for money.

Ulaščik, N. N. Očerki po arkheografii $i$ istočnikovedeniju istorii Belorussii feodal'nogo perioda. 'Nauka', Moscow, 1973. 303 pages. Indexes. Illustrations.

There have surely been few works published in recent years that have more deserved the a'tention of the historian of Byelorussia than this one. The author has succeeded in amassing a vast amount of archival and bibliographical data, and puitting it into a form that is both informative and, surprising as it may seem, entertaining.

Ulaščik makes it quite clear in the introduction that he is primarily concerned with a descripicion of those publications which contain archival material on Byelorussia proper. He therefore includes a discussion on the kind of terminology devised during the 19th century to describe Byelorussia, as distinct (if it was distinguished at all) from ethnic Lithuania, Poland or Russia proper, and on 'the political considerations involved.

The book is divided into three chapters. Chapter I lists the publications of the period 1824-1862 (including the Akty Zapadnoj Rossii and the Sbornik Mukhanova). Chapter II deals with the most importan" period in the development of Byelorussian historiography and of the study of related archives, 1864-1915. The author describes in detail the activities of the 'Vilenskaja arkheografičeskaja komissija' and the collections of documents it produced. Attention is also paid to the relevant volumes in the series Akty Južnoj $i$ Zapadnoj Rossii and Russkaja Istoričeskaja biblioteka. In general the collections in the second chapter are divided between those which emanated from government-inspired bodies (such as the Vilna commission just mentioned) and those compiled and produced by private persons, e.g. the Vitebskaja starina and S. A. Beršadskij's Arkhiv. Chapter III takes the listing and analysis of publica- tions into the Soviet period; the last series to be included is the Historyja Bietarusi $\bar{u}$ dakumientach $i$ materyjatach, vol. 1 of which appeared in 1936, and vol. 2 (with the series title amended to Dakumienty $i$ materyjaty pa historyi Bietarusi) in 1940. There is no biblliography apart from the footnotes, but perhaps the whole book should be regarded as a bibliography with exhaustive commentary on each en'ry, arranged in chronological order of publication.

Ulaščik is concerned primarily with the way in which archives were chosen (often at random), the editorial principles adhered to, publica'ion cost, and so on. He succeeds in establishing the authorship of many of the lengthy prefaces which were a feature of several important 19thcentury series. This makes the book a fascinating study of the way in which history is written. The author's own talent as historian (he received his training during 'the Inbietkult period) comes to the fore in his criticism of the shortcomings of many members of the Vilna commission, among whom were to be found 'true amateurs only in the sense that they loved the salary attached to their post, and in his sideswipes at the Polish historian Mienicki. It also shows in occasional lengthy but always in'teresting discussions of the actual archives and what they contain, in addition 'to the collections in which they appeared. Thus the reader is treated "to a detailed account of the income and expenditure of Mahiloŭ on pp. 184-5, and to the fact that the cripples of the same town were apparently organized in a 'union', being under 'the control of 'kaleckije starosty'. On p. 194 we learn of a divorce being granted ' $z$ nedobroho meškan'ja', and elsewhere there is an account of a 
monastery which raised a band of mercenary soldiers to attack a nunnery. Points of primary importance for the study of Byelorussian history are also raised by Ulašcik in his brief discussion of the various Byelorussian units of measure, and in his careful distinction between the terms 'mirnyj sud' and 'kopny sud'. These points are of course necessitated by his analysis of the inaccuracies in the compilation under discussion. Heavy irony is surely present on p. 271. Here the author is discussing I. I. Jakovkin's compilation Zakonodatel'nyje akty Velikogo knjažestva Litovskogo XV-XVI vv. (published as part of the series Dokumenty $i$ materialy po istorii narodov SSSR in Leningrad, 1936). He points out that Jakovkin's bibliography omits to mention I. I. Lappo's vitally important Litovskii statut $1588 \mathrm{~g}$., $t$. 1. Issledovanija, č. 1. 'It is possible', says Ulaščik, 'that Lappo's work, which appeared in Kaunas in 1934, had not managed to reach Leningrad by 1936'. There is irony 'too when he describes the 1926 congress of research workers in Byelorussian archives and archaeology as the first (and so far only) congress of its type.

The author's asides are occasionally surprising, or even mildly irritating. In discussing a documen't of 1688 , he adds that it mentions the village of Žoldino, 'where the BelAZ car factory is now'. A then-and-now comparison is probably iniended, but it is tempting to wonder how many Soviet readers of this book know where Žoldino actually is and what it is like with a car factory, let alone what it was like without one in 1688. Excessive space is devoted on pp. 237-8 to berating Sapunov for translating Polish Podlasie as Poles'e, a mistake which ought to be self-evident to most, if not all, of his readers. Similarly, do we really need to be told tha't Polish ' $z$ ' = Russian ' 3 ', whereas ' $\dot{\mathrm{z}}$ ' $=$ ' $\mathbb{R}$ '?

A much larger question mark hangs over the assumption that it is possible, or indeed desirable, to separate the history of Byelorussia, particularly in the 15th-17th centuries, from the history of the Grand Duchy of Lithuania as a whole. The title of Chapter II of vol. 1 of the series Historyja Bielarusi $\breve{u}$ dakumientach $i$ materyjalach is indicative of the problem: 'Obrazovanije Velikogo knjažestva Litovskogo na territorii Litvy i Belorussii'. In real terms this is putting the cart before the horse - the Grand Duchy preceded the arrival on the political scene of both Lithuania and Byelorussia. Any historian of the Grand Duchy faces the enormous task of gathering together material which, for reasons which have little to do with historical reality, has been hived off in a number of different directions. At least in the case of Byelorussia he has been well served by Ulaščik. The author emerges as a man who writes with enthusiasm about 'the history of his native country; it is not for nothing that the book opens with the famous verse by Kupała which begins:

Ad pradziadoŭ spakon viakoŭ

Mnie zastalasia spadčyna;

Moreover he writes withou't any apparent ideological adherence, other than that of scholarly precision, which would tend to colour his judgements.

There is no doubt that this book will be of great service to historians of Byelorussia and of the whole Grand Duchy of Lithuania for a long time to come. It is not only an invaluable bibliograhical tool, but also a fascinating study of the 19th- and 20th-century pioneers of Byelorussian historical science.

\section{J. Dingley}

Plato. Gorgias. Z hreckaha tekstu na biełaruskuju movu perakłaŭ, papiaredziŭ uvodzinami i ahledziŭ kamentarami Jan Piatroŭski. Z dadatkam hrecka-biełaruskaha słoŭnika. 'Byelorussian Charitable Educational Fund', Gainesville (Fa.), 1973. 149, 101 pages.

The atten'tion of everyone interested in the development of Byelorussian culture should be drawn to the pioneering work being carried out in Florida by Pastor Jan Piatroŭski. This volume is the third in the series 